\title{
Pembangunan dan penilaian model hasrat mengguna aplikasi mudah alih penasihatan penyakit panaman lada hitam
}

\begin{abstract}
ABSTRAK
Kajian hasrat mengguna aplikasi mudah alih dalam domain pertanian masih kurang diterokai. Penggunaan m-Pertanian seperti aplikasi memberi faedah apabila menerima dan mengguna aplikasi tersebut. Tujuan kajian ini adalah untuk membangun sebuah model tingkah laku hasrat mengguna (HM) aplikasi mudah alih penasihatan penyakit untuk tanaman lada hitam (m-Naslada), mengesah model HM serta membangun prototaip m-Naslada berdasarkan beberapa faktor daripada model HM. Model kajian dibangun berteraskan model penerimaan teknologi. Faktor yang dipertimbangkan pada model kajian adalah mobiliti, kesederhanaan, norma subjektif, keserasian, inovasi kendiri, efikasi kendiri, kualiti maklumat, interaktif, persepsi kebergunaan, persepsi mudah guna dan tingkah laku hasrat mengguna. kaedah kuantitatif dengan instrumen soal selidik baharu diguna bagi mengesah model kajian. Tinjauan sebenar dilaksana dengan mentadbir instrumen kepada 200 orang pekebun kecil lada hitam di Sarawak. Data diperoleh dianalisis mengguna pendekatan Pemodelan Persamaan Berstruktur melalui kaedah Kuasa Dua Terkecil Separa (KDTS), ujian analisis kuasa statistik post hoc dan ujian Kebagusuaian Global (KBG). Hasil kajian mendapati faktor Mobiliti, Kesederhanaan, Norma Subjektif, Keserasian, Inovasi Kendiri, Efikasi Kendiri, Persepsi Kebergunaan, Persepsi Mudah Guna mempengaruhi Tingkah Laku Hasrat Mengguna. Berdasarkan ujian analisis kuasa statistik post hoc, pelaksanaan kajian ini didapati memberi impak sebenar kepada populasi pekebun kecil lada hitam. Hasil analisis ujian KBG mendapati model HM boleh dipakai dalam kajian ini. Secara keseluruhan, model dan instrumen kajian boleh menjadi indikator bagi mengukur hasrat mengguna sesebuah aplikasi mudah alih untuk domain pertanian.
\end{abstract}

Katakunci: Aplikasi mudah alih; Hasrat mengguna; Model Penerimaan Teknologi; Pertanian 